\title{
La Anfictionía Pileo-Délfica y la solución judicial de controversias interestatales en el mundo griego clásico: ¿Un antecedente antiguo de la Corte Internacional de Justicia? ${ }^{1}$
}

\author{
The Pylaeo-Delphic Amphictyony and the judicial settlement of interstate disputes in the \\ classical Greek world: An ancient antecedent to the International Court of Justice?
}

\section{Emiliano J. Buis}

ebuis@derecho.uba.ar

Profesor Titular Regular de Derecho Internacional Público (Facultad de Derecho, UBA y UNICEN) Profesor Adjunto Regular de Lengua y Cultura Griega (Facultad de Filosofía y Letras, UBA) Investigador Independiente de CONICET.

\begin{abstract}
Resumen: $¿$ En qué medida la experiencia griega antigua puede servir para comprender el sistema de solución pacífica de controversias del derecho internacional actual? Este trabajo pretende recuperar la experiencia normativa de la Anfictionía Pileo-Délfica en tiempos clásicos (s. V y IV a.C.) para ilustrar los fundamentos, la utilidad y los beneficios de recurrir a medios jurisdiccionales institucionalizados de resolución de diferendos. En los cruces entre derecho interestatal y religión panhelénica, por un lado, y entre las decisiones anfictiónicas y la justicia doméstica de cada pólis, por el otro, el ejemplo griego descripto permite alertar acerca del uso político de las organizaciones de la época, de la manipulación diplomática de sus órganos y del papel significativo de las ligas en términos de obtención de prestigio y consagración hegemónica.
\end{abstract}

Palabras clave: Solución pacífica de controversias - historia del derecho internacional - Anfictionía PileoDélfica - antigüedad griega

\begin{abstract}
To what extent can the ancient Greek experience be used to understand the system of peaceful settlement of disputes in current international law? This work tries to recover the normative experience of the Pylaeo-Delphic Amphictyony in classical times (5 $5^{\text {th }}$ Centuries BCE) to illustrate the foundations, the utility and the benefits of resorting to institutionalized jurisdictional means of dispute resolution. At the crossroads between interstate law and Panhellenic religion, on the one hand, and between the Amphictyonic decisions and domestic justice of poleis, on the other one, the Greek example under analysis allows us to alert about the political use of contemporary organizations, the diplomatic manipulation of their organs and the significant role of leagues in terms of obtaining prestige and hegemonic consecration.
\end{abstract}

Key Words: Peaceful settlement of disputes - bistory of international law - Pylaeo-Delphic Amphictyony - Greek antiquity

1 Artículo enviado el 13.04.2020 y aceptado el 05.05.2020.

Número de página no utilizable para citar 
La Anfictionía Pileo-Délfica y la solución judicial de controversias interestatales en el mundo griego clásico Emiliano J. Buis

\section{Introducción ${ }^{2}$}

A Hortensia Gutiérrez Posse

In memoriam magistrae

Existe una tendencia generalizada, en la doctrina del derecho internacional, a considerar que el orden jurídico vigente para regular las relaciones entre los sujetos de la comunidad internacional fue establecido recién en época moderna. Esta ficción de la modernidad del derecho internacional encuentra su razón de ser en la determinación arbitraria de una sucesión de hitos históricos que, desde los tratados que forman parte de la Paz de Westfalia (1648), han ido delineando la naturaleza, el objeto y los fundamentos del sistema jurídico internacional. Ya me he ocupado de develar que esta exclusión del mundo pre-moderno dentro de las reflexiones históricas del derecho internacional, que resulta mayoritaria en los volúmenes sobre el tema, constituye una operación ideológica destinada a rechazar como origen de la disciplina a todas aquellas normas establecidas en un contexto diferente de aquel inspirado por la lógica moderna (Buis, 2020). ${ }^{3}$

Frente a esta ficción originaria, la lectura de las fuentes clásicas muestra con claridad que, contrariamente a esa opinión generalizada, en el mundo antiguo ya existían institutos que pueden ser descriptos como parte de un derecho internacional particular. En ese sentido no solamente es posible identificar en los testimonios jurídicos y literarios de la época verdaderas fuentes de normas internacionales — como tratados o normas consuetudinarias - sino todo un régimen de solución de controversias que constituye un antecedente muy concreto de las prácticas actuales sobre el tema. Esta última constatación es particularmente importante, dado que se trata de un tema que no ha recibido la atención debida en la doctrina internacionalista. Incluso es posible afirmar que, en aquellos escasos textos aislados que al hablar de la historia del derecho internacional dedican algunas páginas al mundo antiguo, se advierte que la referencia a los

2 Una versión previa de este trabajo fue presentada en las V Jornadas Chileno-Argentinas de Derecho Internacional sobre el tema "Solución Pacífica de Controversias Internacionales", que tuvo lugar en la Facultad de Derecho de la Universidad de Chile los días 26 y 27 de septiembre de 2019. Este trabajo se enmarca en la producción correspondiente al Proyecto de Investigación DECyT "Hacia una sociología del Derecho Internacional Humanitario: valores, creencias y percepciones como condicionamientos normativos informales en tiempos de conflicto armado" (DCT1807), aprobado y financiado en el marco del Programa de Acreditación Institucional de Proyectos de Investigación en Derecho, Secretaría de Investigación de la Facultad de Derecho de la UBA (Res. CD 582/18). También corresponde a los trabajos desarrollados en el contexto del mi plan bienal de investigación de CONICET sobre "Cuerpos diplomáticos, emociones convenidas. La representación física de los afectos inter-estatales sobre la escena cómica ateniense (siglos V-IV a.C.)".

3 Para citar aquí sólo un ejemplo de este fenómeno, es posible mencionar que en el Oxford Handbook of the History of International Law (Fassbender \& Peters, 2012), no hay referencia alguna a la antigüedad. 
mecanismos de solución de diferendos suele estar ausente, ya que la atención se centra más bien en temáticas muy concretas como los acuerdos militares o la diplomacia. Así, en el caso del célebre texto de Bederman (2001) — que reinauguró los estudios sobre el derecho internacional antiguo - no se le presta atención a los modos de solución de controversias internacionales vigentes durante la antigüedad clásica, que se mencionan de modo superficial a la hora de desarrollar otros aspectos tenidos por relevantes. Este tratamiento incidental del tema podría tener una explicación: suele ser un lugar común que, como se encontraba profundamente ligada al factor religioso, la "responsabilidad" de las póleis o de las entidades políticas antiguas no era en efecto considerada como "jurídica” en términos actuales. En tanto las instancias de solución de conflictos estaban casi siempre ligadas al plano de lo sagrado y no a una "legalidad" como la que acostumbramos reconocer a partir de la configuración del orden europeo del s. XVII, no sorprende entonces la ausencia de reflexión sobre los dispositivos formales empleados en las civilizaciones antiguas para superar las diferencias bilaterales.

El modesto propósito de estas páginas es saldar en parte esta cuenta pendiente en la doctrina referida a la historia antigua del derecho internacional. Se propone aquí, de modo preciso, contribuir a una recuperación de la experiencia normativa de la antigua Grecia para dar cuenta de un ejemplo en el que se vislumbran con claridad los alcances jurídicos de aquellos medios jurisdiccionales de solución de controversias, en particular cuando se trata de la intervención de una organización interestatal mediante el arbitraje o el arreglo judicial. Me refiero al caso concreto de la Anfictionía Pileo-Délfica que, a través de su actuación, permite dar cuenta de una práctica "judicial" que se ha descripto como no muy alejada de los tribunales internacionales creados en el s. XX. El relevamiento de sus funciones y de su actuación en época clásica (s. V y IV a.C.) permitirá a mi juicio recontextualizar nuestras reflexiones acerca de la solución de disputas internacionales y de los inconvenientes prácticos que hoy acarrea el cumplimiento de las decisiones de los órganos jurisdiccionales.

\section{La solución de controversias en el mundo griego}

La inexistencia de un concepto de subjetividad no impide que encontremos en las fuentes antiguas una interesante reflexión en torno de la responsabilidad de todos aquellos entes políticos abstractos compuestos por los distintos individuos que forman parte del conjunto de ciudadanos. ${ }^{4} \mathrm{El}$ orador Isócrates, en su discurso Sobre la paz, muestra bien que, de modo

4 Nos hemos ocupado en Buis (2018a: 71-106) de pensar las póleis como entes político-jurídicos particulares, independientes y autónomos, que se obligaban mutuamente en sus relaciones a respetar ciertas normas

Número de página no utilizable para citar 
La Anfictionía Pileo-Délfica y la solución judicial de controversias interestatales en el mundo griego clásico Emiliano J. Buis

semejante a lo que ocurre con las personas físicas, las ciudades-Estado eran merecedoras de sanción cuando se comportaban de manera contraria a las normas vigentes (8.119-120):

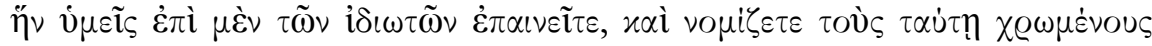

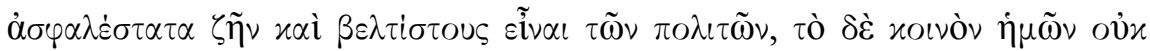

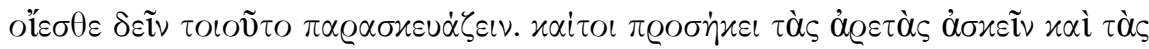

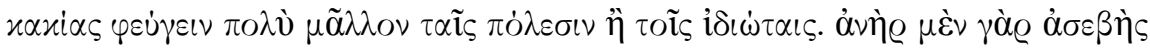

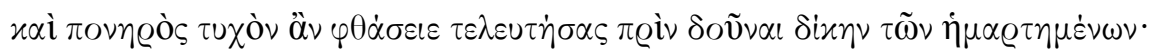

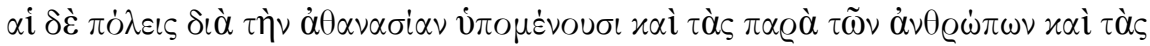

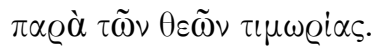

Mientras ustedes alaban la prudencia en los individuos y creen que aquellos que la practican disfrutan de la existencia más segura y son los mejores entre sus compañeros ciudadanos, no consideran adecuado que la comunidad en conjunto la practique. Y sin embargo es conveniente que las ciudades-Estado mucho más que los individuos cultiven las virtudes y aparten el vicio. Pues un hombre que es impiadoso y depravado podría morir sin pagar el castigo por sus hechos, pero las ciudades-Estado, dado que son inmortales, tarde o temprano deben ser sometidas a la sanción por parte de los hombres y de los dioses. ${ }^{5}$

El pasaje muestra de manera clara que, así como ocurre que los individuos se comportan bien o de un modo contrario a lo esperable, las póleis también se pueden conducir de manera correcta o incorrecta, y en este último caso estarán sujetas a castigo (timōría). Estas circunstancias, en las cuales las ciudades llevan adelante hechos que generan la necesidad de una sanción posterior, incluyen aquellas situaciones en las que se identifican claramente controversias entre las ciudades, si entendemos "controversias" —en su sentido contemporáneo- como un desacuerdo o situación sobre puntos de hecho o de derecho, una oposición o divergencia de intereses o de tesis jurídicas entre dos Estados". ${ }^{6}$ En muchos casos se trataba de experiencias de violencia armada, en las que una ciudad-Estado denunciaba la incursión ilícita de otra en el territorio bajo su control; en otros casos, podía ocurrir la violación de una tregua o acuerdo vigente, o el

comunes (nómoi koinoi). Esta noción nos permite superar el debate, tan interminable como poco fructífero, en torno a la calificación de la pólis como un "Estado".

5 Las ediciones de los textos griegos citados en este trabajo aparecen consignadas en la bibliografía final. En todos los casos, las traducciones de los originales al castellano nos pertenecen.

6 Según la célebre definición de la Corte Permanente de Justicia Internacional, Caso de las Concesiones Mavrommatis en Palestina (Grecia c. Reino Unido), Sentencia sobre el fondo del asunto, 30 de agosto de 1924, Serie A, nº 2 a 13. La Corte Internacional de Justicia (CIJ) ha recuperado el concepto en el Caso del Suroeste Africano (Etiopía y Liberia c. Sudáfrica), Decisión sobre excepciones preliminares, 20 de diciembre de 1962, 319, pp. 344-346. Se trata de un concepto que la CIJ ha empleado incluso de modo muy reciente como argumento central para justificar el rechazo de las pretensiones de las Islas Marshall en el Caso de las obligaciones referidas a las negociaciones relativas al cese de la carrera armamentística nuclear y al desarme nuclear (Islas Marshall c. India, Pakistán y Reino Unido), Decisiones sobre excepciones preliminares, 5 de octubre de 2016. 
incumplimiento de las cláusulas de un convenio aceptado por ambas partes. Son múltiples los ejemplos en los que los Estados antiguos manifestaban tener opiniones distintas sobre un tema, y no son pocas las instancias en las que intentaron llegar a un arreglo para superar esas dificultades.

En aquellos casos, no es difícil notar que la solución más habitual frente a estas situaciones de desavenencias solía ser el recurso a la fuerza armada. Lejos se estaba, en este sentido, de la existencia de un marco jurídico basado en la obligación de solucionar las controversias de modo pacífico -como ocurre hoy con el principio establecido en el art. 2.3 de la Carta de las Naciones Unidas $-{ }^{7}$ o mismo de la prohibición de la amenaza o uso de la fuerza consagrada actualmente en el inciso siguiente. ${ }^{8} \mathrm{La}$ licitud de la fuerza armada en el mundo antiguo no implicaba, sin embargo, la ausencia de recursos alternativos a medios de solución pacífica de divergencias basados en la negociación directa o en la intervención de terceros. De hecho, es posible dar cuenta de varios ejemplos en los que las partes en una controversia decidían de común acuerdo superar sus malentendidos y resolver sus inconvenientes, o incluso convocar a árbitros o jueces extranjeros para que pudieran suministrar una salida al conflicto.

Los casos en los que se decidió convocar a árbitros extranjeros para cumplir estas funciones son cuantiosos; en general se trata de supuestos en los que dos póleis vecinas confiaban en nacionales de una tercera ciudad la posibilidad de aportar una solución ajena a un viejo conflicto bilateral. ${ }^{9}$ A veces eran las organizaciones de ciudades las que se encargaban directa o indirectamente de llevar adelante la logística necesaria para asegurar la intervención de estos árbitros o de terceros componedores. ${ }^{10}$

Cuando no se nombraban jueces o árbitros ad hoc, procedentes de una tercera pólis, para llevar adelante un procedimiento de arreglo de diferencias, el consejo federal de la liga, según muestran los testimonios antiguos, tenía jurisdicción para ocuparse ella misma de la identificación de

7 "Los Miembros de la Organización arreglarán sus controversias internacionales por medios pacíficos de tal manera que no se pongan en peligro ni la paz y la seguridad internacionales ni la justicia". La Carta de las Naciones Unidas se firmó el 26 de junio de 1945 en San Francisco y entró en vigor el 24 de octubre del mismo año.

8 Se trata del artículo 2.4: "Los Miembros de la Organización, en sus relaciones internacionales, se abstendrán de recurrir a la amenaza o al uso de la fuerza contra la integridad territorial o la independencia política de cualquier Estado, o en cualquier otra forma incompatible con los Propósitos de las Naciones Unidas".

9 Acerca de la figura de estos jueces extranjeros, que eran llamados para solucionar conflictos entre privados o entre póleis, cf. Robert (1973).

10 Según Westermann (1907: 198), el principio del arbitraje interestatal y su puesta en práctica nacieron precisamente en el mundo griego. Acerca de la importancia del arbitraje internacional en este contexto helénico, cf. Raeder (1912); Tod (1913); Roebuck (2000 y 2001), Magnetto (2008); Ager (2013); Bertoli (2013); Magnetto (2016) y Carty (2017). Si bien los ejemplos provenientes de los tiempos clásicos son significativos, lo cierto es que la documentación que poseemos aumenta muchísimo cuando se relevan los testimonios de época helenística, como puede advertirse de un recorrido por las inscripciones recopiladas por Ager (1996) y Magnetto (1997). 
La Anfictionía Pileo-Délfica y la solución judicial de controversias interestatales en el mundo griego clásico Emiliano J. Buis

delitos e imponer sanciones a sus miembros. Me interesa aquí examinar los pocos ejemplos conservados de este tipo menos habitual de procedimiento de naturaleza pacífica, vinculado con la puesta en práctica de verdaderas instancias judiciales en el marco de estas organizaciones o ligas en el plano internacional. En este sentido, se recuperará el accionar institucional de la llamada Anfictionía Pileo-Délfica; expondremos los alcances de su función y su importancia para el buen entendimiento entre diversas póleis a partir del período arcaico, a los efectos de poner en perspectiva, en términos históricos, los mecanismos hetero-compositivos de carácter jurisdiccional en materia de derecho internacional.

\section{La Anfictionía Pileo-Délfica y su actuación jurisdiccional}

Como se ha adelantado, en tiempos clásicos (en un sentido amplio, pensamos en los siglos VII a III a.C.) la Grecia antigua estaba marcada por la coexistencia política de una serie de ciudades independientes, conocidas como póleis. Según nos trasmiten las fuentes con que contamos, estas póleis eran entidades libres capaces de dictar su propio orden normativo (autonomía) y su administración de justicia (autodikia). La existencia de una multiplicidad de ciudades-Estado desembocó en la firma de alianzas, que a su vez repercutieron en el nacimiento de distintos esquemas federales, signados por variadas modalidades de integración en función de los intereses circunstanciales de quienes decidían unirse. Es entonces frecuente hallar un buen número de asociaciones militares (symmakhiai) y ligas religiosas (amphiktyoníai) entre póleis, cada una con sus particularidades. Con ellas, se ha dicho que los pueblos helénicos fueron conocedores de formas semejantes a lo que la modernidad concibe como organizaciones internacionales, es decir, como entidades compuestas por Estados, fundadas en algún instrumento constitutivo, capaz de tener una voluntad diferente de aquellas de cada uno de sus miembros y regida por el orden jurídico vigente a las relaciones entre esos entes soberanos. ${ }^{11}$

La terminología griega respecto de las confederaciones y ligas de carácter político es vaga e incluye términos como koinón (que apunta a la idea de una construcción conjunta) o sympoliteía (vinculado con un régimen de gobierno en común, especialmente en tiempos helenísticos) (Pascual, 2007). En todo caso, estos fenómenos parten de la base de que, en ellos, las ciudadesEstado se someten voluntariamente a las decisiones tomadas por un conjunto de órganos que ellas integran. Así, en estas experiencias de alianza la confederación suele tener a su cargo todos

11 Estos son los cuatro criterios que, dentro de la flexibilidad existente, reconoce Urueña (2008: 4) para identificar una organización internacional en la actualidad. La bibliografía reciente sobre el tema es inabarcable; para profundizar estos criterios mínimos pueden consultarse las introducciones genéricas de Bennet \& Oliver (2002), Armstrong, Lloyd \& Redmond (2004), Amerasinghe (2005) y Rittberger \& Zangl (2006). Para una mirada histórica (aunque a partir del s. XIX) puede consultarse además Reinalda (2009).

Número de página no utilizable para citar 
los asuntos de interés común, incluyendo por supuesto la conducción de los temas militares y el manejo de las relaciones exteriores. Se trata de una suerte de competencia delegada, que desplaza aquella que discrecionalmente poseía la pólis de modo particular. ${ }^{12}$ Lo que estas asociaciones de enorme alcance y proyección a lo largo del período clásico y helenístico— ${ }^{13}$ permiten observar es la presencia de entidades superpuestas, que, como veremos, dejan entrever una constante tensión entre el esfuerzo colectivo y la independencia y autonomía locales. ${ }^{14}$ Se percibe una dualidad, no siempre resuelta, entre dos niveles de toma de decisiones que no necesariamente se organiza formalmente: por un lado el plano de acción federal, y por otro el andarivel doméstico (Rizakis, 2015: 128), todo ello en una suerte de système-monde en el que coexisten formas, actores y comunidades políticas que interactuaban en redes regionales y hegemónicas (Vlassopoulos, 2007: 195-202).

Nos interesa aquí hablar de las anfictionías, es decir, de aquellas asociaciones de ciudades o pueblos, de carácter religioso, cuyo propósito era administrar un santuario compartido. ${ }^{15}$ En particular, la llamada Anfictionía Pileo-Délfica o Liga Anfictiónica fue sin dudas una de las principales, sino la más trascendente en términos de capacidad de acción y proyección (Bederman, 2001: 60 y 168-171). Se trataba de una agrupación de éthne, ${ }^{16}$ organizada en este caso en torno de la defensa y protección del santuario de Apolo en Delfos y de Deméter en Antela, cerca de las Termópilas. ${ }^{17}$ La Anfictionía Pileo-Délfica, que existió desde el arcaísmo hasta bien entrado el imperio romano, ${ }^{18}$ presentaba en tiempos clásicos una serie de características que han llevado a muchos a relacionar con lo que en la actualidad concebimos como una organización internacional.

12 Ténékidès (1954: 39), quien además distingue tres tipos de asociaciones entre las que osciló el federalismo griego: las asociaciones confederales (donde los Estados siguen siendo autónomos de hecho y de derecho), las imperiales (en las que un Estado dirige la política exterior de todos) y las confederales falseadas por la actitud de uno de los miembros que se arroga poderes discrecionales; cf. Ténékidès (1954: 179).

13 Mackil (2013b: 305) sostiene que, hasta 323 a.C., alrededor de un 40\% de las póleis de las que tenemos conocimiento eran miembros de algún koinón. En los dos siglos siguientes, quizás motivado por la progresiva crisis de la ciudad-Estado como centro de poder, el porcentaje aumentó exponencialmente.

14 Pérez Martin (2001: 79-83) distingue factores centrífugos y centrípetos para explicar esta tensión.

15 Adcock \& Mosley (1975: 229); Mackil (2013b: 307). Acerca de una comparación entre las anfictionías y las alianzas militares (symmakhía) —otro de los modos privilegiados de agrupamiento de ciudades en tiempos arcaicos-, cf. Tausend (1992).

16 Entendemos por éthnos un grupo nacional o pueblo sin estructura urbana; si bien tiene alcances jurídicos, se trata de un concepto diferente del de pólis porque constituye una unidad político-religiosa que representa una estructura estatal primitiva, como dice Funke (2013: 451). Acerca de esta fluctuación terminológica, véase Mackil (2013b: 304). Cf. Rzepka (2002)

17 La asociación se interesaba de manera particular por el santuario — que era el lugar en el que se desarrollaban los Juegos Píticos- y no tanto por el oráculo de Delfos propiamente dicho, como sostiene Morgan (1990: 184185).

18 El hecho de que se diga que la integraban éthne y no póleis ha hecho pensar que sus orígenes son preclásicos. Después del s. III d.C., ya deja de haber testimonios que demuestren su continuidad; cf. Sánchez (2013: 376).

Número de página no utilizable para citar 
La Anfictionía Pileo-Délfica y la solución judicial de controversias interestatales en el mundo griego clásico Emiliano J. Buis

En términos de composición, por ejemplo, la participación original estaba limitada a los miembros fundadores - que enviaban a los encuentros oficiales a los llamados hieromnémones, "los que recuerdan las cosas sagradas"-, ${ }^{19}$ que eran doce si seguimos las fuentes antiguas. ${ }^{20}$ En los orígenes legendarios de la Anfictionía se halla una narrativa genealógica que se remonta a los vínculos derivados de la figura de Anfictión, un héroe epónimo, rey de Termópilas y luego de Atenas, quizás hermano de Heleno -el antepasado común de todos los griegos-, quien a través de la creación de la liga facilitó que se aunaran los intereses de las distintas colectividades vecinas bajo el interés común de la necesidad de preservar cultos arcaicos. ${ }^{21}$ Con el tiempo, lo que sí se conoce bien es que a los primeros integrantes originarios se les sumaron otros grupos étnicos, provenientes de zonas más alejadas, de modo que se amplió el número de partes involucradas en la toma de decisiones y se extendió su red en términos geográficos, mucho más allá de los nexos territoriales de vecindad. ${ }^{22}$ Según Pausanias, el ingreso de nuevos miembros estuvo a veces acompañado del retiro de otros (Descripción de Grecia 10.8.2), lo que da cuenta de la laxitud de la condición de membresía:

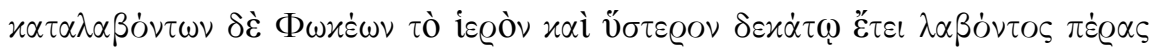

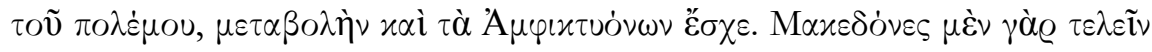

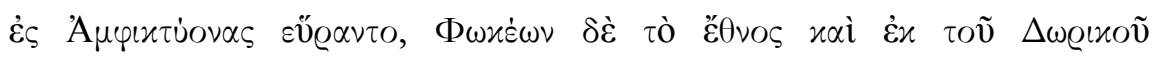

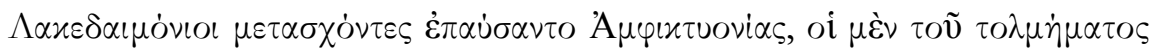

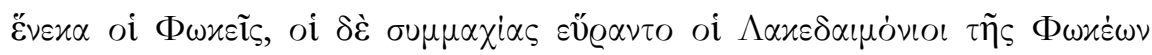

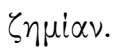

Pero cuando los focios tomaron el templo y después de diez años la Guerra llegó a su fin, hubo un cambio en los asuntos de los anfictiones. Pues por un lado los macedonios lograron ingresar, mientras que el pueblo de los focios y los lacedemonios, un parte del pueblo dorio, dejaron de ser miembros de la

19 Acerca de los nombres de estos hieromnémones, véase Lefèvre (2005).

20 Pausanias (Descripción de Grecia, 10.8.2) identifica cuáles fueron las ciudades griegas originarias invitadas a agruparse según la tradición legendaria: "Dicen que el propio Anfictión convocó al consejo común a estos pueblos de origen griego: jonios, dolopes, tesalios, enianos, magnesios, malios, aqueos de Ftiótide, dorios, focios

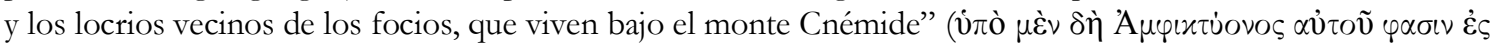

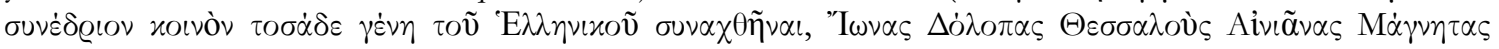

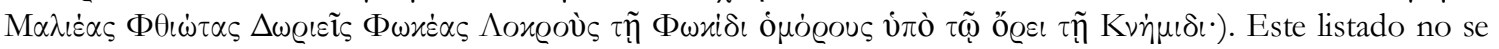
corresponde exactamente con aquel provisto en Esquines (Sobre la Embajada [2], 116) y en Teopompo FGH 115 F63, lo cual ha motivo varios intentos de compatibilización. Sobre las dificultades para reconstruir la composición originaria de la Anfictionía, así como sus miembros posteriores, véase Phillipson (1911: 5-7), y sobre el amplio espectro étnico que la identificaba, véase Hall (2015: 30).

21 Funke (2013: 454) sostiene que se trata de un mito etiológico secundario, creado para legitimar la génesis de una liga sustentada originalmente en una lógica espacial.

22 Cf. Kahrstedt (1922: 385). 
Anfictionía; los focios a causa de sus atrevimientos, los lacedemonios como sanción por hacerse aliado con los focios. ${ }^{23}$

Según Estrabón (Geografía 9.3.7), las ciudades se reunían dos veces por año en encuentros regulares, en primavera y fines de otoño, llamadas pylaía porque tenían lugar en Pilas o

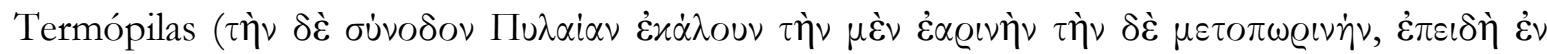

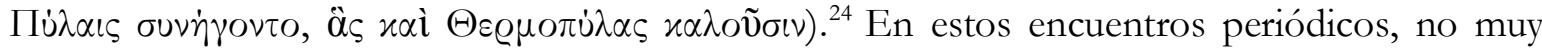
diferentes de los períodos de sesiones ordinarias de las organizaciones contemporáneas, se discutían los temas previstos en la competencia de la Anfictionía, como también detalla Estrabón en el mismo pasaje citado:

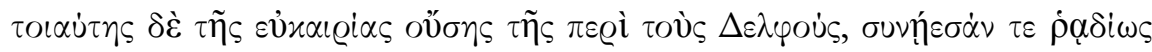

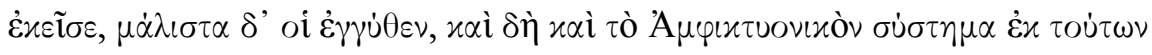

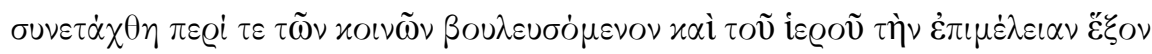

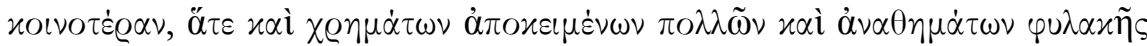

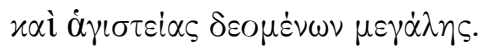

Siendo estas las ventajas de la zona de Delfos, llegaban fácilmente ahí, sobre todo quienes estaban cerca. Y ciertamente la Liga Anfictiónica fue organizada a partir de estos, tanto para deliberar sobre los asuntos comunes como para mantener más en común el cuidado del templo, porque se depositaron allí mucho dinero y muchas ofrendas, necesitándose de vigilancia y gran religiosidad.

Es evidente que, desde sus orígenes, la asociación se ocupó de modo estricto de las cuestiones sagradas vinculadas con los santuarios, incluyendo el libre paso de los peregrinos, comerciantes y de aquellos que participaban de los eventos y festivales religiosos, como los famosos Juegos Píticos. ${ }^{25}$ Algunos testimonios muestran que, a pesar de esta fuerte impronta religiosa, la

23 Sabemos, por ejemplo, que en 279 a.C. la Anfictionía admitió a los etolios como miembros, en gratitud por haber protegido el santuario de las invasiones galas. Hacia el año 191 a.C. la liga contaba con diecisiete miembros, aunque no todos tenían ya el mismo peso en la toma de decisiones.

24 Para Bowden (2003: 68) estos encuentros en realidad eran verdaderos festivales a los que asistían representantes de las ciudades vecinas. En su opinión, los pylágorai (mencionados por ejemplo en Hdt. 7.213.2), que muchos identifican como aquellos oficiales enviados por las ciudades miembros que se reunían en dichos encuentros de la Anfictionía (Sánchez, 2001: 497), habrían sido los organizadores de las ceremonias festivas. Se discute todavía en qué consistían los roles diferenciados de los hieromnémones y los pylágorai: Sánchez (2001: 506-507) sostiene, por ejemplo, que mientras los primeros eran los jueces que resolvían los conflictos, los segundos cumplían el rol de abogados de parte. Giovannini (2007: 372-373) sostiene que los bieromnémones eran los delegados principales, ya que siempre se los menciona en primer lugar; los pylágorai, seguramente más numerosos, seguramente participaban de las deliberaciones del consejo pero solamente votaban en circunstancias excepcionales.

25 Lefèvre (1998: 236) sostiene que la organización de estos juegos era quizás la tarea más importante de la Anfictionía, descartando que se tratara de un instrumento de poder: se trataba simplemente de fijar un espacio de prestigio entre los miembros. Hornblower (2007) reconoce precisamente en esto, a pesar de la falta de 
La Anfictionía Pileo-Délfica y la solución judicial de controversias interestatales en el mundo griego clásico Emiliano J. Buis

Anfictionía sirvió pronto de foro para la discusión de temas de índole política. (Ehrenberg, 1969: 109; Roux, 1979; Forrest, 1982: 312-318; Hall, 2002: 134-154; Sánchez, 2013: 375; Funke, 2013: 457-458; Funke, 2016) ${ }^{26}$ El texto de Estrabón corrobora esta utilidad institucional de la liga al mencionar la importancia financiera de la asociación: a partir del s. VI a.C., las reuniones del consejo fueron empleadas como un instrumento de poder por parte de las póleis más importantes, que pretendían hacer valer una progresiva hègemonía para controlar las cuentas y presionar a las más débiles.

A pesar de la limitación documental con que contamos, ${ }^{27}$ el papel que cumplió la Anfictionía durante los conflictos armados del período clásico no puede soslayarse. Cuando el Oráculo de Delfos se independizó de la ciudad de Crisa, los habitantes de esta ciudad instalaron una serie de impuestos de peaje a quienes atravesaban la zona, lo que llevó a la intervención por parte de la Anfictionía que, agotados los medios pacíficos de solución de controversias, decidió atacar a Crisa durante la llamada Primera Guerra Sagrada (596-585 a.C.). La acción culminó con la destrucción de la ciudad y la consagración de las tierras a Apolo (Bederman, 2001: 169-170). En 572 a.C., el festival local de la Pitia fue colocado bajo la estricta supervisión de la Anfictionía, contando con un status panhelénico. En 449-448 a.C., la Segunda Guerra Sagrada tuvo lugar cuando los focios quisieron adueñarse del santuario y los espartanos enviaron un ejército para impedir esta apropiación. ${ }^{28}$

Tanto el rol militar de la Anfictionía — entendido como un ejercicio de seguridad colectivacuanto su dominación política como espacio de negociación contaban con un sólido apoyo jurídico. ${ }^{29}$ Por lo pronto, en lo que hacía a su aspecto normativo, los miembros estaban obligados

fuentes suficientes al respecto, un verdadero rol "político" de la Anfictionía. Con respecto a los deberes de la asociación referidos a la administración del espacio del santuario, una inscripción (IG II $\left.{ }^{2} 1126.40-44\right)$ da cuenta de la tarea de mantener los caminos y puentes que empleaban los peregrinos que marchaban hacia Delfos; cf. Hall (2007: 100).

26 Esta opinión es muchas veces resistida. Ya Boak (1921: 377) y Tausend (1992: 34-47) decían que la asociación tenía solamente fines religiosos y no políticos; Bowden (2003) ha retomado esta idea. Para Nakategawa (1994: 144), si bien la Anfictionía cumplía un rol importante como instrumento de poder en los s. V y IV a.C., seguramente su utilidad política era menor a la de otro tipo de alianzas militares contemporáneas. En todo caso, parece ser cierto que la liga contribuyó a la creación posterior y al desarrollo de federaciones regionales, como ocurrió en Beocia; cf. Singor (2009: 588).

27 Esta documentación literaria y epigráfica es clasificada por Giovannini (2007: 373) en tres grupos: el material vinculado a la gestión y protección de los bienes de Apolo, aquel referido a la organización de los Juegos Píticos, y los decretos más generales sobre la protección de los santuarios y su inviolabilidad.

28 Sin embargo, luego Pericles le devolverá a los focios el control sobre Delfos hasta la Paz de Nicias de 421 a.C., en que Delfos recuperará su independencia. No será la única vez en que los focios capturan la ciudad. En 356 a.C. lo harán de nuevo, motivando una nueva guerra sagrada (la tercera) que concluirá diez años después con la expulsión de los focios de la Anfictionía. Habrá que esperar a comienzos del s. III a.C. para que se produzca la readmisión focia. También durante el s. IV a.C. los tesalios y los beocios intentaron valerse de la Anfictionía para asegurarse un poder hegemónico sobre la Grecia central Cf. Sánchez (2013: 376).

29 Según Phillipson (1911: 11), "it is clear that the Delphic amphictyony (...) exercised a great influence directly or indirectly in the promotion of international comity, and in the regularization of, and insistence on, many principles of interstatal practice."

Número de página no utilizable para citar 
a pronunciar públicamente un juramento, en el que se dejaba constancia de la necesidad de cumplir y respetar los principios comunes que regían el funcionamiento de la asociación. El texto de este juramento ha sido transmitido en un pasaje del orador Esquines (Sobre la Embajada [2], 115):

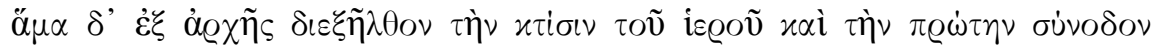

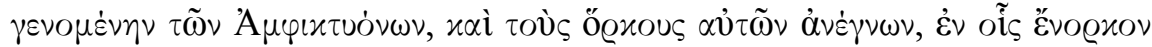

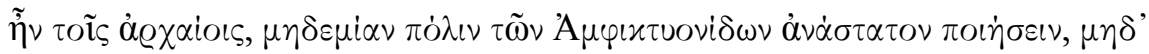

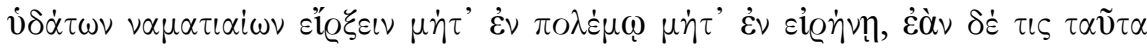

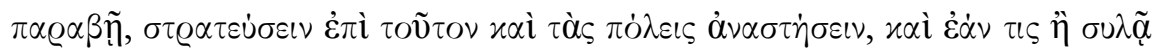

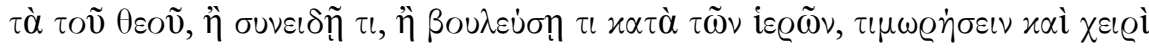

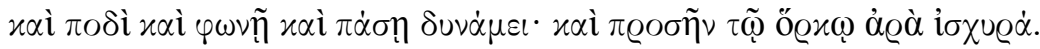

Al mismo tiempo circulé desde el comienzo por la historia de la fundación del templo y de la primera reunión que hubo de los anfictiones, y leí sus juramentos, en los que los antiguos habían jurado que no arrasarían ninguna ciudad de los anfictiones, ni les cerrarían las corrientes de agua en tiempos de guerra o de paz, y que en caso de que alguno violara esto, ellos marcharían con el ejército contra este y arrasarían sus ciudades, y que, en caso de que alguno violara algún lugar inviolable del dios o fuese cómplice de dicha violación, o complotara contra los lugares sagrados, lo castigarían con la mano, el pie y la voz y con toda su fuerza; y se le sumó al juramento una fuerte maldición.

Si se acepta la veracidad de este testimonio, ${ }^{30}$ en el respeto de la inmunidad de los lugares sagrados y la prohibición de afectar los cursos de agua algunos han identificado una arista humanitaria que se desprendería del tenor del juramento (Larsen, 1944: 147; Kiechle, 1958; Ilari, 1980: 364-366; Guillermand, 1994: 195; Pérez Martin, 2001: 93). ${ }^{31}$ A ello, sin embargo, debe sumarse un aspecto más pragmático ligado con la conveniencia de mantener la integridad del acuerdo: me refiero a la posibilidad concreta de la fijación de sanciones para el caso de incumplimientos, incluyendo la agresión armada. En el juramento, pues, se observa la profunda imbricación que existía entre el plano divino, sustentado en la lógica de la inviolabilidad de los santuarios, y la toma de decisiones políticas vinculadas con la imposición por la fuerza de un orden de cosas determinado en el seno de la Anfictionía. (Bederman, 2001: 69).

En sus orígenes, la liga preveía una igualdad jurídica entre las póleis que la conformaban, atribuyéndole a cada una de ellas dos votos (es decir, el mismo peso en derecho) a la hora de tomar una medida (Giovannini, 2007: 372). Asimismo, había todo un conjunto de "normas

30 Sánchez (1997), por ejemplo, considera que se trata de un texto que en realidad viene de fuentes tardías y dudosas. Acerca de las dudas sobre su datación, véase Low (2007: 111, n. 117).

31 Sin embargo, "it is true that it insisted upon certain humane observances in war waged among members of the league, but it did not aim to prevent war even between them” (Boak, 1921: 377). 
La Anfictionía Pileo-Délfica y la solución judicial de controversias interestatales en el mundo griego clásico Emiliano J. Buis

anfictiónicas" que constituían la base del rol institucional que le había sido asignado a la asociación (Estrabón, Geografía 9.3.7):

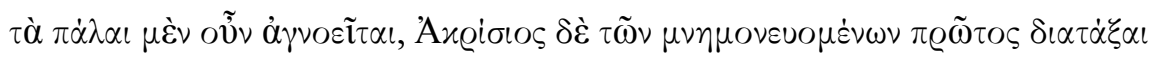

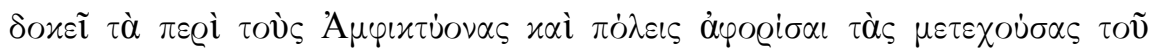

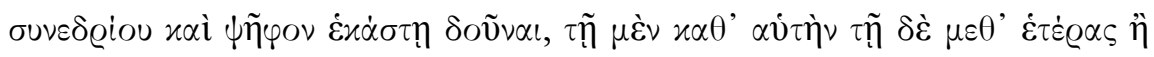

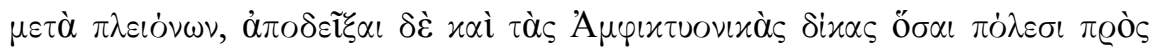

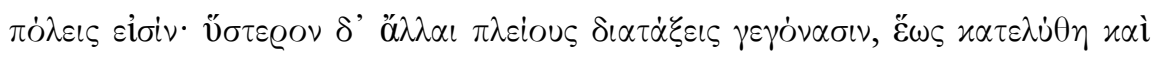

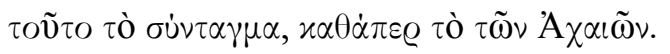

Se desconocen los hechos antiguos, pero parece que, de aquellas cosas que se recuerdan, Acrisio fue el primero en organizar los asuntos de los anfictiones, determinó las ciudades que participaban en el consejo y dio a cada una un voto, a cada una de modo separado y a otra de modo conjunto con una segunda o con varias, y proclamó las normas anfictiónicas que las ciudades tienen hacia las otras. Luego hubo otras muchas organizaciones, hasta que esta organización, como la de los Aqueos, se disolvió.

Estas leyes comunes a la asociación — por lo que se lee en estas líneas — se refieren a las normas que resultaban aplicables a las relaciones entre las póleis que aceptaban voluntariamente pasar a ser sus miembros activos. La existencia de un consejo (synédrion), como la máxima autoridad, permitía respaldar el respeto de estos principios (Ehrenberg, 1969: 110-111; Giovannini, 2007: 372). ${ }^{32}$ Interesantemente, una ambigüedad en el texto griego siembra la duda respecto del alcance de esos principios compartidos, ya que las dikai Amphiktyonikaí mencionadas serían, por un lado, reglas destinadas a fomentar la asociación entre las ciudades-Estado, y a la vez podían configurar un sistema de regulación de aquellas controversias y aquellos enfrentamientos que se pudieran

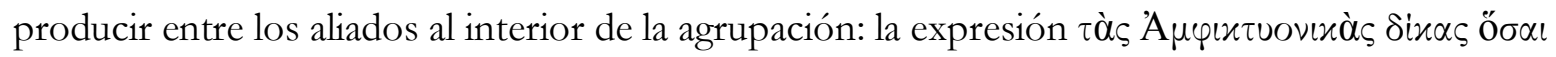

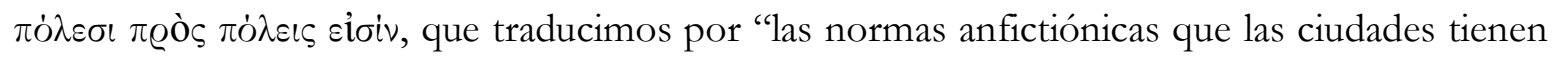
bacia las otras" podría significar al mismo tiempo "que las ciudades tienen contra las otras", si

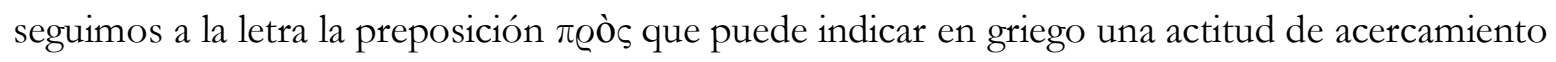
o bien de hostilidad. Sin embargo, parece claro que el objetivo nunca fue prevenir el uso de la fuerza entre sus miembros.

En términos prácticos, parece evidente que estas normas a las que se hace mención se ponían en juego cuando surgía alguna controversia entre las póleis que integraban el orden colectivo. Como hemos señalado al comienzo, lo que pretendo hacer aquí no es estudiar el conjunto de aquellos casos en los que se establecía la designación de árbitros ad hoc de una ciudad, sino más bien ocuparme del rol institucional de la Anfictionía Pileo-Délfica en términos de solución

32 Mucho más debatible es la función de la asamblea (ekeklesía) de la Anfictionía, que era el otro órgano importante, pero del que las fuentes dicen muy poco. Al respecto, ver Pérez Martin (2001: 91), para quien la asamblea estaba integrada por todos los griegos presentes en Delfos durante las fiestas religiosas.

Número de página no utilizable para citar 
pacífica de disputas. En el lenguaje del derecho internacional moderno, apunto a aquellos casos de solución jurisdiccional, sea a través de un sistema de arbitraje institucionalizado preestablecido o bien de arreglo judicial. ${ }^{33}$ Es indudable, por supuesto, que no es posible en el caso griego trazar una distinción tajante entre árbitros y jueces como la que existe hoy. ${ }^{34}$ Ello, no obstante, no afecta la búsqueda de algunos ejemplos ilustrativos que indican que la liga se comportó en muchos casos como órgano jurisdiccional para decidir acerca de la responsabilidad de algunas de las póleis que eran sus miembros, incluso fijando una sanción en caso de encontrar violaciones al orden establecido de modo conjunto (Bederman, 2001: 169). Es el caso, por ejemplo, de la condena impuesta a Mégara por el ataque recibido por unos peregrinos provenientes del Peloponeso (Bürgel, 1877: 148; Piccirilli, 1973: 25-27, n. 6; Piccirilli, 1972: 40). Plutarco ofrece una síntesis de los hechos (Questiones graecae, 59):

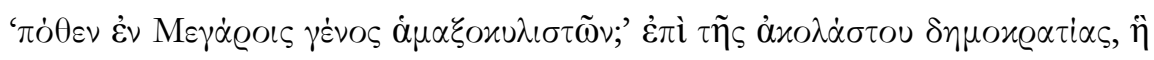

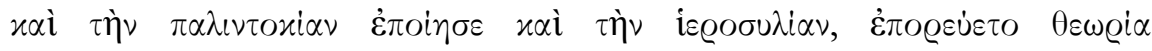

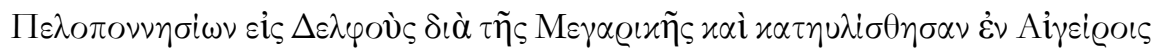

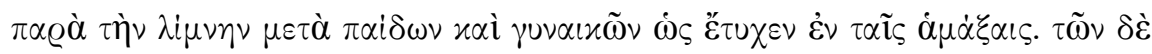

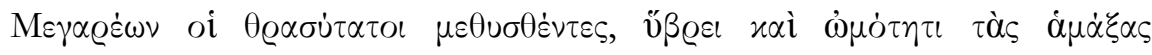

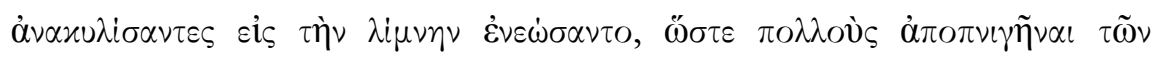

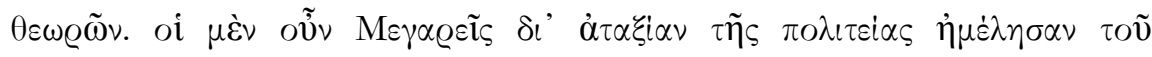

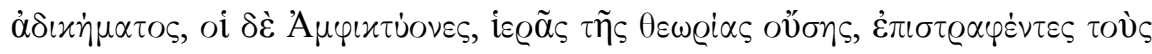

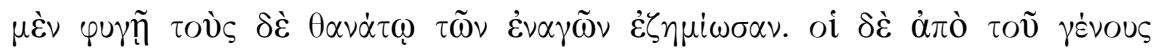

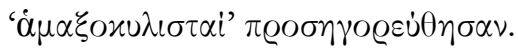

¿De dónde vino entre los megarenses la tribu de los “empujadores de carros"? En tiempos de la democracia irrestricta, que produjo la devolución de interés y el sacrilegio de los templos, una embajada sagrada de los peloponesios atravesó la Megáride hacia Delfos y acampó por azar en sus carros, con sus mujeres e hijos, en Egeiros junto al lago. Pero los más osados de los megarenses, borrachos, en su desmesura y salvajismo empujaron los carros y los tiraron al lago, de modo que muchos de los enviados se ahogaron. A causa de la falta de organización de su gobierno los megarenses en efecto no se

33 El artículo 33.1 de la Carta de las Naciones Unidas, que precisamente encabeza el Capítulo VI sobre "Arreglo pacífico de controversias" despliega el principio consagrado en el artículo 2.3 (ya aludido) e identifica estas diversas modalidades de manera clara: "Las partes en una controversia cuya continuación sea susceptible de poner en peligro el mantenimiento de la paz y la seguridad internacionales tratarán de buscarle solución, ante todo, mediante la negociación, la investigación, la mediación, la conciliación, el arbitraje, el arreglo judicial, el recurso a organismos o acuerdos regionales u otros medios pacíficos de su elección". No me ocuparé aquí de aquellos métodos considerados "diplomáticos", que no implican una solución de carácter vinculante para las partes, sino de los “jurídicos” o "jurisdiccionales”, y en particular de aquellos que están institucionalmente establecidos con cierto grado de permanencia y previsibilidad.

34 De hecho, en los testimonios preservados muchas veces resulta imposible hacer esa distinción conceptual, que no resulta a mi entender relevante para el contexto de la diplomacia helénica.

Número de página no utilizable para citar 
La Anfictionía Pileo-Délfica y la solución judicial de controversias interestatales en el mundo griego clásico Emiliano J. Buis

ocuparon del crimen, pero los Anfictiones, dado que la embajada era sagrada, tomaron conocimiento del hecho y castigaron a algunos con el exilio y a otros con la muerte. Y los descendientes de estos hombres fueron llamados "empujadores de carros".

La fuente relata entonces el momento en el que una theōría o embajada sagrada, ${ }^{35}$ que tenía por objetivo visitar el templo de Delfos, se detuvo en territorio de Mégara y acampó en la costa de un lago. Algunos habitantes locales, embriagados, se dejaron llevar por la cólera y arrastraron algunos de los carros hasta el lago, donde algunos de los viajantes murieron. ${ }^{36}$ Tras un intento fallido por pedir indemnización a los megarenses, quienes "no se ocuparon del crimen", los sobrevivientes presentaron un reclamo en su contra ante la propia Anfictionía, que al fin tomó la decisión de expulsar a algunos de los responsables y de condenar a otros a la pena capital (Bonner \& Smith, 1943: 4-5). Resulta evidente, en este caso, que los oficiales presentes en el consejo anfictiónico se comportaron como si fuesen los jueces de un tribunal, en tanto se atribuyeron a sí mismos la determinación de las sanciones correspondientes por la agresión cometida por los megarenses, a falta de decisión interna acerca de la investigación del crimen alegado.

Un segundo incidente, que podríamos datar hacia el 476/5 a.C., apunta a la misma capacidad jurisdiccional de la liga y se refiere a la sentencia de condena impuesta a los dólopes que habían saqueado a un grupo de mercaderes de Tesalia (Bürgel, 1877: 199; Piccirilli, 1972: 42; Piccirilli, 1973: 80-82, n. 17). En este caso es Plutarco quien, en sus Vidas Paralelas, transmite los detalles fácticos (Cimón, 8.3-4):



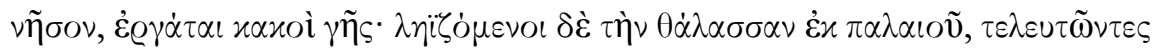

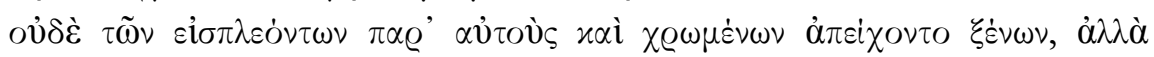

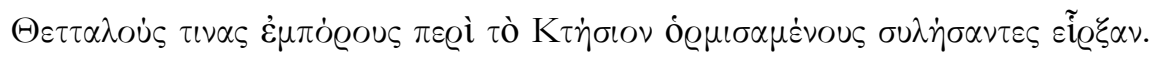

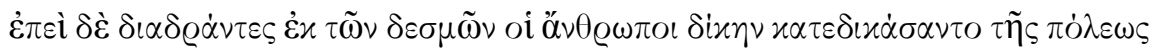

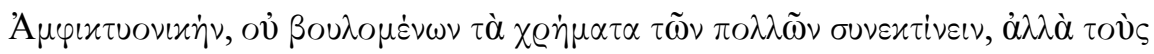

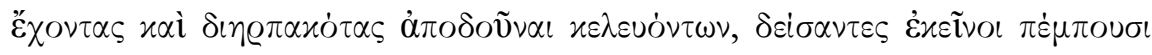

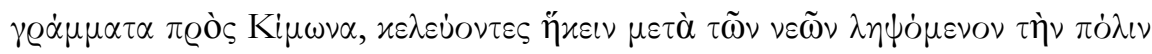

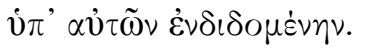

Y también fundaron Esciros, que Cimón tomó por esta razón. Los dólopes residían en la isla, pero eran malos trabajadores de la tierra. Se dedicaron a la piratería en el mar desde antiguo, y al final empezaron a saquear a los extranjeros que llegaban navegando con mercancías, pero despojaron a unos

35 Sobre las theōriai y las redes que se tramaban en torno de estas delegaciones religiosas, cf. Malkin (2011: 114117).

36 Piccirilli (1973: 25) fija la fecha del episodio hacia el 570-560 a.C. 
comerciantes tesalios que habían anclado cerca de Ctesio y además los apresaron. Y cuando escaparon de prisión, estos hombres pidieron justicia y obtuvieron sentencia contra la ciudad, y los dólopes no quisieron restituir los bienes, sino que ordenaron a quienes tenían los objetos saqueados a devolverlos. Y estos, aterrorizados, le enviaron una carta a Cimón para que viniera con sus barcos a tomar la ciudad, que ellos mismos le entregarían.

Ante el pedido de justicia de los tesalios que fueron injustamente apresados, la Anfictionía se ocupó del tema y decidió que los dólopes en Esciro serían sancionados con la obligación de devolver los bienes obtenidos por medio de los actos de piratería. ${ }^{37}$ Este episodio, una vez más,

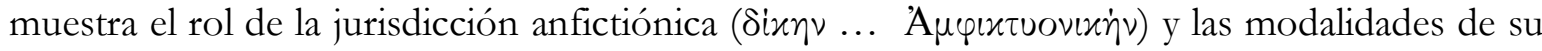
actuación a pedido de la parte afectada por un comportamiento de otro considerado como injusto o ilegal (Flacelière, 1937: 380).

Los delegados de la Anfictionía Pileo-Délfica también oficiaron de árbitros en una controversia sometida por los delios hacia el 345/343 a.C., quienes protestaban contra el derecho de los atenienses a controlar el templo de Delos (Niese, 1963: 221; Bürgel, 1877: 203). Se desconoce con exactitud el alcance la disputa o su real contenido, ${ }^{38}$ pero se sabe por testimonios epigráficos que la decisión de la Anfictionía terminó favoreciendo a Atenas, dado que contamos con fuentes posteriores que nos indican que la ciudad seguirá en posesión del templo. Evidentemente, en este caso, a pesar de tratarse de unos hechos referidos en un comienzo al control de territorio sagrado, la resolución arbitral o judicial de la disputa tuvo importantes consecuencias políticas en términos estratégicos. ${ }^{39}$ En los alegatos que se elaboraron para justificar sus pretensiones, Atenas designó a Esquines - aunque luego el orador terminó siendo remplazado por Hipérides_-, ${ }^{40}$ mientras que los delios fueron representados por Eutícrates. El episodio, que terminó con el triunfo ateniense gracias a la elaborada elocuencia de Hipérides, ${ }^{41}$ permite inferir la potencialidad de intervención política de la liga, mediante su función jurisdiccional, en asuntos relacionados con la imposición territorial y la posesión de bienes sagrados.

37 A este evento se refieren también los pasajes de Tucídides, Historia de la Guerra del Peloponeso 1.98.2, Diodoro Sículo, Biblioteca Histórica 11.60.2 y Cornelio Nepote, Vida de Cimón 2.5. Cf. Phillipson (1911: 10).

38 Es posible que se haya tratado simplemente de un asunto vinculado con el templo, cf. Westermann (1907: 205).

39 De hecho, nada parece sugerir que se haya tratado de una situación en la que se argumentara una violación de la ley sagrada sino de un asunto esencialmente político, como han concluido Raeder (1912: 170) y Ténékidès (1931: 9). Roussel (1940: 338-339) da cuenta de esta tensión política de época al sostener que, por ejemplo, Atenas no envió representantes a la reunión de la Anfictionía de otoño del 346 a.C. Más recientemente, Sánchez (2001: 247-250) ha considerado que se trató de un falso arbitraje.

40 Demóstenes, Sobre la corona [18] 134, sobre el nombramiento fallido de Esquines, ver Adcock \& Mosley (1975: 230)

41 Se trata de la Oración Delia, preservada solo de modo fragmentario (Hipérides F76, cf. Engels 1989: 74-80). Ver además Bonner \& Smith (1943: 5). 
La Anfictionía Pileo-Délfica y la solución judicial de controversias interestatales en el mundo griego clásico Emiliano J. Buis

Diodoro Sículo (Biblioteca Histórica, 16.29) comenta el caso de que, luego de la batalla de Leuctra en 371 a.C., los tebanos presentaron una denuncia contra Esparta ante los anfictiones, ya que los espartanos habían atacado la ciudadela de Tebas. La Anfictionía impuso en este caso una multa de quinientos talentos que, como no fue pagada, se terminó aumentando a mil. Más allá de que se tratara de una intervención lícita (ambas partes eran miembros de la liga y el asunto presentaba un carácter religioso, ya que la incursión militar tuvo lugar durante la festividad religiosa de las Tesmoforias), ${ }^{42}$ es interesante destacar los motivos por los cuales los espartanos se negaron en un comienzo a pagar la multa impuesta: consideraban que habían sido condenados injustamente ( $\lambda \dot{\varepsilon} \gamma o v \tau \varepsilon \varsigma \alpha \dot{\alpha} \delta i \varkappa \omega \varsigma \ldots \varkappa \alpha \tau \alpha \delta \varepsilon \delta \iota x \dot{\alpha} \sigma \theta \alpha l, 16.29 .3)$. El ejemplo muestra la resistencia que podían oponer ciertas ciudades-Estado a la actividad judicial de la liga, actividad que en determinados casos podía ser percibida como resultado de una decisión que no estaba fundada en la justicia (Low, 2007: 117-118).

Un último ejemplo permite mostrar otro aspecto de esta relación entre la liga y sus miembros, y se refiere a la tensión que a veces se percibe entre la jurisdicción de la Anfictionía y la administración judicial doméstica en cada ciudad-Estado. Cuando hacia el año 365 a.C. algunos habitantes de Delfos fueron juzgados y condenados por los anfictiones al exilio y se les confiscaron sus propiedades, un testimonio epigráfico nos indica que los atenienses consideraron que el juicio había sido conducido de modo contrario al derecho de los anfictiones y al orden

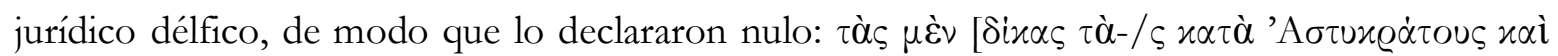

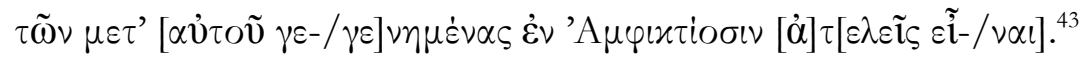

Esta respuesta ateniense frente a la decisión del consejo de los anfictiones es significativa, porque deja entrever que un Estado podía de modo unilateral, y según su propio criterio, dejar sin efecto un veredicto pronunciado por los oficiales o representantes de la liga (Bonner \& Smith, 1973: 8). Esto da cuenta de los desafíos que se planteaban entre el ejercicio de la justicia por parte de la asociación y el derecho que le cabía a cada ciudad-Estado de imponer su propia legislación y juzgar los asuntos en sus propios tribunales. ${ }^{44}$ Se trata de una reacción por parte de los atenienses que demuestra que, para que pudiera avanzar en sus funciones propiamente jurisdiccionales, un ente colectivo como la Anfictionía Pileo-Délfica debía contar con el consentimiento de cada uno de los miembros involucrados en la disputa y en ningún caso actuar en contra de sus intereses (Ehrenberg, 1969: 111).

42 Jenofonte, Helénicas 5.2.29.

43 SEG 175 , líneas 22-25.

44 Acerca de la distribución de los roles jurisdiccionales entre las comunidades federales y las ciudades, véase Mackil (2013a: 354-355). 


\section{A modo de conclusión}

La práctica de la Anfictionía Pileo-Délfica en materia de solución de controversias internacionales durante los s. V y IV a.C. permite observar interesantes particularidades, que nos llevan a discutir, como ya han hecho otros, las eventuales analogías con las lógicas actuales que caracterizan el funcionamiento de las instituciones jurisdiccionales y su participación a la hora de poner límite a los diferendos entre Estados. ${ }^{45}$ En efecto, frente a lo que debía de ser una práctica frecuente en la antigüedad - la implementación de instancias arbitrales ad hoc, algo habitual en las alianzas militares o ligas regionales de la época-,${ }^{46}$ lo que llama la atención en los ejemplos recién explorados es la existencia de un cuerpo de oficiales o magistrados que, con cierta permanencia, se ocupaban de lidiar en las reuniones del synédrion con los asuntos que eventualmente les fuesen remitidos. Ello nos podría llevar a preguntarnos si, efectivamente, la Anfictionía Pileo-Délfica podría ser considerada un verdadero precursor de las organizaciones internacionales actuales.

La doctrina ha brindado opiniones contradictorias al respecto. Mientras que algunos críticos han reforzado los puntos de contacto para aseverar que la liga debe ser considerada un antecedente importante de un sistema como el de la Sociedad de Naciones, las Naciones Unidas o incluso la Organización del Tratado del Atlántico Norte (Vinogradoff, 1922: 163; Séfériadès, 1930), ${ }^{47}$ otros

45 Por supuesto recordemos que nos hemos ocupado de una asociación que se extendió en el tiempo durante casi ochocientos años, lo que necesariamente implica que sufrió profundos cambios durante su desarrollo. En este trabajo hemos orientado el foco hacia el período clásico, y sobre este período elaboramos las conclusiones que siguen. Un futuro trabajo deberá, pues, indagar en fuentes más tardías para advertir el desempeño judicial de la Anfictionía en tiempos helenísticos e imperiales. Los ejemplos de época helenística muestran también la efectividad de la solución de controversias en el marco de asociaciones interestatales.

46 Nos hemos ocupado en un trabajo previo (Buis, 2018b), por ejemplo, de examinar el caso de la Liga Aquea durante el período helenístico, que merece particular mención porque desarrolló una práctica institucionalizada, con una fuerte base jurídica, en lo referente a la solución de controversias de sus miembros por medio del llamamiento de terceros; cf. Beck (1997: 55- 66). Es de destacar que la propia Liga estaba en condiciones de determinar quiénes intervendrían en la instancia jurisdiccional, imponiéndose incluso en ciertas ocasiones a la voluntad de las ciudades contendientes. Pueden hallarse ejemplos en Aymard (1938: 182-183) y Rizakis (2015: 129). Para una mirada más reticente acerca del rol judicial de la Liga, puede consultarse Harter-Uibopuu (1998: 129). Una nueva inscripción de Mesena sobre una disputa con Megalópolis (SEG 58.370, fechada en 180 a.C. y hallada recientemente, a fines de 2004) proporciona evidencia acerca del papel que jugaba la confederación cuando había controversias entre sus miembros. En efecto, el texto muestra bien que Megalópolis se dirigió a las autoridades de la Liga a los efectos de legitimar su acción e iniciar un proceso de solución de controversias

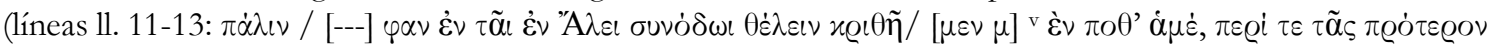
$\chi \omega ́ \varrho \alpha \varsigma$, "de nuevo, en el consejo — sýnodos — en Elis [los megalopolitanos] querían ser juzgados por las regiones de antes”); cf. Arnaoutoglou (2009-2010: 189), Luraghi \& Magnetto (2012: 526-527).

47 En tiempos de la Guerra Fría, y casi de modo irónico, Forrest (1957: 172) comparó la Anfictionía precisamente con el accionar de la Organización del Tratado del Atlántico Norte para sugerir su funcionalidad militar y su parcialidad. 
La Anfictionía Pileo-Délfica y la solución judicial de controversias interestatales en el mundo griego clásico Emiliano J. Buis

se han ocupado de plantear una serie de diferencias considerables que no pueden dejarse de lado al momento de comparar ambas experiencias históricas (Boak, 1921; Ténékidès, 1931, 1956: 583-596). ${ }^{48}$ Para estos últimos, tratándose de una agrupación muy limitada de éthne —y luego, en tiempos clásicos, de póleis_ sostenida sobre métodos bastante rudimentarios, la Anfictionía fue un ejercicio bastante primitivo de fraternidad religiosa, muy alejado de la posibilidad de encarnar la idea de una institución organizada destinada a promover la justicia internacional (Bederman, 2001: 171). Se ha incluso hablado, en estos círculos de pensamiento, de un entusiasmo exagerado por parte de quienes se apresuran a vincular la actuación de la liga con la realidad de los organismos propios del derecho internacional contemporáneo (Lefèvre, 1995: 19).

Quienes postulan distancias insalvables entre la Anfictionía Pileo-Délfica y las organizaciones internacionales actuales lo hacen, en general, a través de dos tipos de argumentos. Por un lado, desde el punto de vista interno, alegan que la Anfictionía carecía de un espíritu pacificador o de una idea subyacente de justicia o de moral, pilares quizás imprescindibles de los intentos asociativos modernas de los últimos cien años (Ténékidès, 1931: 10). Por el otro, en una perspectiva externa, argumentan que la imposibilidad de trazar similitudes se debe a las conceptualizaciones irreconciliables de fondo en que hace a la existencia misma del derecho internacional: la ausencia en la antigüedad de una noción de Estado o de una pretensión subyacente de universalidad hacen que todo intento pretendido de analogía se torne infructuoso (Ténékidès, 1931: 11-15).

En todo caso, en lo que hace de modo particular a la implementación de la función jurisdiccional del consejo anfictiónico, que es lo que concretamente me ha interesado en estas páginas, sería factible indicar que la asociación parece haber tenido un papel bastante limitado en tanto tribunal (Westermann, 1907: 205) y que, cuando ha cumplido el rol propio de una corte interestatal, lo ha hecho en asuntos de carácter religioso, esto es, en procesos restringidos a cuestiones relacionadas con las normas anfictiónicas aplicables a la gestión de los santuarios que se hallaban bajo su control (Raeder, 1912: 171; Ténékidès, 1931: 8). ${ }^{49}$ Es cierto por lo tanto que, así las cosas, no tiene mayor sentido postular seriamente una comparación con el régimen onusiano actual sustentada en criterios formales. ${ }^{50}$ Ello no obsta, en mi opinión, a que no existan otros vínculos interesantes entre la experiencia de la Anfictionía y aquella que caracteriza a nuestras instituciones colectivas integradas por Estados.

48 Su historia es tan oscura que no es posible imaginar comparación alguna; Lefèvre (1995).

49 Pérez Martin (2001: 92) llega a afirmar que los hieromnémones eran un colegio sagrado que no actuaba en nombre de Grecia sino del dios Apolo, de modo que, en vez de normas jurídicas, las reglas que regían sus actos eran dogmas religiosos.

50 "Promoting historical consistency between the contemporary international institutions such as the United Nations and the temple of Apollo at Delphi in the Antiquity is required to consider historically distinctive natures of the structures in which international dispute settlement proceedings partake" (Calap \& Erdogan, 2015: 24).

Número de página no utilizable para citar 
En primer lugar, los ejemplos vistos permiten llegar a la conclusión de que no es necesario hablar de fraternidad o de universalidad para comprender los objetivos de un mecanismo de solución de controversias en el plano internacional. De hecho, los asuntos sometidos a análisis en el caso de la Anfictionía Pileo-Délfica indican con suficiente claridad que no siempre a la hora de imaginar la resolución de una disputa nos encontramos frente a un intento de reconciliación, sino que con frecuencia se trata de zanjar una diferencia de opiniones a partir de la determinación de la legalidad o ilegalidad de cierto comportamiento. La experiencia pileo-délfica lleva a inferir que el elemento emotivo ligado a la idea de superar los obstáculos del desentendimiento mediante un espíritu conciliador no resulta pues indispensable para llevar adelante una práctica efectiva de arreglo arbitral o judicial.

En segundo lugar, es preciso rescatar el carácter político notorio que, más allá de lo sustancial o de lo procesal, suele estar implicado en estas experiencias de solución institucional de controversias. Así, aunque focalizados en disputas ligadas a la dimensión religiosa de los cultos a Apolo y Deméter, en términos abstractos los ejemplos descriptos muestran bien cómo el recurso a los hieromnémones funcionaba a menudo como instrumento de presión cuando la búsqueda de una reparación interestatal se veía como imposible y entonces era preciso recurrir a un tercero para intervenir. ${ }^{51}$ En este sentido, el intento de apropiarse del funcionamiento de la Anfictionía para hacer avanzar la agenda de los Estados más poderosos es prueba fiel de su utilidad relativa en lo que se refería a la expresión pública de un poder, tanto real y simbólico, de las póleis hegemónicas. ${ }^{52}$

En tercer lugar, y para finalizar, los documentos examinados permiten concluir que no es posible ignorar la tensión inherente entre la actuación de este tercero - la Anfictionía en el caso-y los órganos de la propia pólis, que buscaban recuperar el espacio de poder delegado en cuanto se avecinaba una solución que unilateralmente era vista como injusta o inapropiada. El hecho de que Atenas haya declarado nula una decisión de los anfictiones resulta altamente significativo si se pretende examinar las posibles consecuencias de la actividad de la liga, puesto que muestra que, en caso de que una ciudad-Estado miembro estimara en términos políticos que le resultaba perjudicial aceptar la injerencia de un tribunal interestatal, el argumento de la primacía del orden soberano, autónomo e independiente podía acarrear como efecto la anulación de la decisión emitida por los representantes de la Anfictionía.

51 Coincidimos con Ehrenberg (1969: 109) cuando sostiene que no es posible plantear en estas cuestiones una oposición entre religión y política.

52 Escribiendo muy poco después del nacimiento de la Sociedad de Naciones, Boak (1921: 383) se preguntaba a la luz de la comparación con las asociaciones griegas: "Will the League of Nations fail unless some powerful state or group of states is made responsible for the enforcement of its terms and has coercive power over the remaining members?”. La historia de la Anfictionía Pileo-Délfica permite advertir el rol de diferentes pueblos que pugnaban por la imposición de su hegemonía, como los tesalios (hasta mediados del s. IV a.C.) o los etolios (desde comienzos del s. III a.C.); cf. Giovannini (2007: 371-372).

Número de página no utilizable para citar 
La Anfictionía Pileo-Délfica y la solución judicial de controversias interestatales en el mundo griego clásico Emiliano J. Buis

En síntesis, si de pensar en los orígenes de los métodos actuales de solución de controversias se trata, las fuentes antiguas que nos describen los episodios en que la Anfictionía Pileo-Délfica actuó como órgano judicial dejan en evidencia la tensión propia de toda delegación del poder sancionatorio a órganos extra-domésticos. ${ }^{53}$

En definitiva, entonces, no hace falta recurrir a la identificación de una "membresía" de Estados o a la existencia de sesiones ordinarias o de órganos internos para confirmar la relevancia de la historia institucional griega en los trabajos actuales sobre los medios pacíficos de solución de divergencias. Basta con reconocer la existencia, cerca de Delfos y de Termópilas en los s. V y IV a.C., de una serie de ejemplos específicos que dan cuenta del uso político de las organizaciones de la época, de la manipulación diplomática de sus órganos y de su rol en términos de otorgamiento de prestigio. Esta constatación de los peligros utilitaristas de las alianzas religiosas y estratégicas antiguas alcanza, y con creces, para advertir las profundas implicancias que tiene su estudio si se pretende entender las bases explícitas -y las razones implícitas de convenienciaque sustentan el orden jurídico internacional instalado luego de la primera posguerra. ${ }^{54}$

\section{Referencias bibliográficas}

\section{Fuentes primarias}

\subsection{Decisiones judiciales}

CORTE INTERNACIONAL DE JUSTICIA, Caso de las obligaciones referidas a las negociaciones relativas al cese de la carrera armamentística nuclear y al desarme nuclear (Islas Marshall c. India), Decisiones sobre excepciones preliminares, 5 de octubre de 2016, I.C.J. Reports 2016, p. 255.

CORTE INTERNACIONAL DE JUSTICIA, Caso de las obligaciones referidas a las negociaciones relativas al cese de la carrera armamentística nuclear y al desarme nuclear (Islas Marshall c. Pakistán), Decisiones sobre excepciones preliminares, 5 de octubre de 2016, I.C.J. Reports 2016, p. 552.

53 Como concluye Ager $(2015,486)$ al analizar los medios pacíficos de solución de controversias en el contexto del federalismo griego, si bien las asociaciones o ligas proporcionan un encuadre institucional capaz de mitigar la anarquía, terminan funcionando solamente gracias a un esfuerzo colaborativo constante por parte de sus miembros. Estos marcos jurídicos de acción — como el que hemos visto en el caso de la Anfictionía PileoDélfica - resultan siempre frágiles al depender de voluntades políticas coyunturales y de escenarios estratégicos cambiantes.

54 Se agradecen los comentarios y sugerencias de los editores de la revista y de las/os colegas presentes en el V Jornadas Chileno-Argentinas de Derecho Internacional, que sirvieron para mejorar muchos aspectos del trabajo. Los errores y las imprecisiones que aún permanezcan son enteramente propios. 
CORTE INTERNACIONAL DE JUSTICIA, Caso de las obligaciones referidas a las negociaciones relativas al cese de la carrera armamentística nuclear y al desarme nuclear (Islas Marshall c. Reino Unido), Decisiones sobre excepciones preliminares, 5 de octubre de 2016, I.C.J. Reports 2016, p. 833.

Corte Internacional de Justicia, Caso del Suroeste Africano (Etiopia c. Sudáfrica; Liberia c. Sudáfrica), Decisión sobre excepciones preliminares, 21 de diciembre de 1962. I.C.J. Report (1962), p. 319.

Corte Permanente de Justicia Internacional, Caso de las Concesiones Mavrommatis en Palestina (Grecia c. Reino Unido), Sentencia sobre el fondo del asunto, 30 de agosto de 1924, Serie A, no 2 (Publications of the Permanent Court of International Justice, Collection of Judgments, Leyden: A. W. Sijhoff, 1924).

\subsection{Ediciones de textos literarios clásicos}

Cornelio Nepote, Vidas: ed. Albert Fleckeisen (1886) Cornelius Nepos. Vitae, Leipzig: B. G. Teubner.

Diodoro, Biblioteca Histórica: eds. Bekker, Immanuel, Ludwig Dindorf y Friedrich Vogel (1888-1890) Diodori Bibliotheca Historica, Vol. I-II, Leipzig: B. G. Teubner.

JENOFONTE, Helénicas: ed. Brownson, Carleton L. (1921). Xenophon, vol. II. Cambridge (MA) /London: Harvard University Press /William Heinemann.

Demóstenes, Sobre la corona: ed. Butcher, Samuel Henry (1903). Demosthenis Orationes. Oxford: Clarendon Press.

ESTRABÓn, Geografia: ed. Jones, Horace Leonard (1924). (ed.). The Geography of Strabo. Cambridge (MA)/London: Harvard University Press/William Heinemann.

PAusanias, Descripción de Grecia: eds. Jones, William Henry Samuel y Henry Arderne Ormerod (1918). Pausanias. Description of Greece. Cambridge (MA) /London: Harvard University Press /William Heinemann.

IsÓCRATES, Sobre la Pa: ed. Norlin, George (1929). Isocrates. On the Peace. Areopagiticus. Against the Sophists. Antidosis. Cambridge (MA) /London: Harvard University Press/William Heinemann.

Plutarco, Vidas Paralelas: ed. Perrin, Bernadotte (1914). (ed.). Plutarch's Lives. Cambridge (MA)/London: Harvard University Press /William Heinemann.

PlutArco, Quaestiones Graecae: ed. Bernardakis, Gregorius N. (1889) Plutarch. Moralia. Leipzig: B. G. Teubner.

TuCÍDIDES, Historia de la Guerra del Peloponeso: ed. Jones, Henricus Stuart (1942) Thucydidis Historiae, Vol. 1: Books I-IV, Oxford: Oxford University Press. 
La Anfictionía Pileo-Délfica y la solución judicial de controversias interestatales en el mundo griego clásico Emiliano J. Buis

\subsection{Ediciones de textos jurídicos epigráficos griegos}

AGER, Sheila L. (1996). Interstate Arbitrations in the Greek World, 337-90 B.C.. Berkeley/Los Angeles/London: University of California Press.

HiCKS, Edward Lee y George Francis Hill (1901). A Manual of Greek Historical Inscriptions. Oxford: Clarendon Press.

MAgnetTO, Anna (1997). Gli arbitrati interstatali greci: dal 337 al 196 a.C., vol. II. Pisa: Scuola Normale Superiore.

PICCIRILLI, Luigi (1973). Gli arbitrati interstatali greci, vol. 1 “Dalle origini al 338 a.C.”. Pisa: Marlin.

\section{Fuentes secundarias (bibliografía crítica)}

ADCOCK, Frank y Derek J. Mosley (1975). Diplomacy in Ancient Greece. New York: St. Martin's Press.

AGER, Sheila L. (2013). “Interstate governance: arbitration and peacekeeping”. En Beck, Hans (ed.) A Companion to Ancient Greek Government. Chichester: Wiley-Blackwell, 497-511.

AGER, Sheila L. (2015). "Peaceful Conflict Resolution in the World of the Federal States". En Beck, Hans y Peter Funke (eds.) Federalism in Greek. Antiquity. Cambridge: Cambridge University Press; 471486.

AmerasingHe, Chittharanjan Felix (2005). Principles of the Institutional Law of International Organizations, Second Edition. Cambridge: Cambridge University Press.

Armstrong, David E., Lorna Lloyd y John Redmond (2004). International Organisation in World Politics, 3rd edition. Basingstoke: Palgrave Macmillan.

ARnAOUTOGLOU, Ilias (2009-2010) "Dispute Settlement between Poleis-Members of the Achaean League. A New Source”. Dike, 12-13: 181-201.

AyMARD, André (1938). Les assemblées de la confédération achaienne. Bordeaux: Féret et fils.

Beck, Hans (1997). Polis und Koinon. Untersuchungen zur Geschicbte und Struktur der griechischen Bundesstaaten im 4. Jahrbundert v. Chr. (Historia Einzelschrift 114). Stuttgart: Franz Steiner Verlag.

Bederman, David J. (2001). International Law in Antiquity. Cambridge: Cambridge University Press.

BennetT, A. LeRoy y James K. Oliver (2002). International Organizations: Principles and Issues, 7th edition. Upper Saddle River (NJ): Prentice Hall. 
Revista Tribuna Internacional

Volumen $9 \cdot \mathrm{N}^{\mathrm{o}} 17 \cdot 2020$

ISSN 0719-482X (versión en línea)

BERTOLI, Marcello (2013). "Il ricorso all'arbitrato interstatale nelle relazioni internazionali della Grecia del V secolo". En Bearzot, Cinzia y Emmanuele Vimercati (eds.). La giustizia dei Greci: tra riflessione filosofica e prassi giudiziaria. Milano: Vita e Pensiero: 113-134.

BOAK, Arthur E. R. (1921). "Greek Interstate Associations and the League of Nations”. American Journal of International Law, 15 (3): 375-383.

BONNER, Robert J. y Gertrude Smith (1943). "Administration of Justice in the Delphic Amphictyony”. Classical Philology, 38 (1): 1-12.

BOwDEN, Hugh (2003). "The Functions of the Delphic Amphictyony Before 346 BCE”. Scripta Classica Israelica, 22: 67-83.

BuIS, Emiliano Jerónimo (2018a). Taming Ares. War, Interstate Law, and Humanitarian Discourse in Classical Greece. Leiden/Boston: Brill/Nijhoff.

BUIS, Emiliano Jerónimo (2018b). "Un único cuerpo, un solo poder: notas sobre la Liga Aquea y el rol jurídico de las organizaciones internacionales en la antigüedad griega". En Luterstein, Natalia Marina (ed.). Repensando la subjetividad internacional, Buenos Aires: Colección Serie Académica Sempithidia: 43-54.

BUIS, Emiliano Jerónimo (2020) “The Politics of Anti-Politics: Historiographies of International Law and the Paradox of Antiquity”. En Peters, Anne y Raphael Schäfer (eds.). Politics and the Histories of International Law. Leiden/Boston: Brill/Nijhoff [en prensa]

BÜRGEL, Heinrich (1877). Die pylaesche-delphische Amphiktyonie. München: Ackermann.

Calap, Adil y Özcan Erdogan (2015). "Arbitration and Conflict Resolution in Antiquity (500 BC- 350 BC)". Euras Academic Journal, 3 (1): 23-52.

CARTY, Aideen (2017). "International arbitration in archaic Greece". En Moloney, Eoghan P. y Michael Stuart Williams (eds.). Peace and reconciliation in the classical world, London: Routledge: 148-159.

EHRENBERG, Victor (1969). The Greek State. $2^{\text {nd }}$ edition, London: Methuen \& Co.

ENGELS, Johannes (1989). Studien zurpolitischen Biographie des Hypereides. Athen in der Epoche der lykurgischen Reformen und des makedonischen Universalreiches. München: Tuduv.

FASSBENDER, Bardo y Anne Peters (2012). (eds.). The Oxford Handbook of the History of International Law. Oxford: Oxford University Press.

FLACELIÈRE, Robert (1937). Les Aitoliens à Delphes : contributions à l'bistoire de la Grèce centrale au IIIe siècle av. J.-C. Paris: E. de Boccard.

FORREST, W. G. (1957). “Colonisation and the Rise of Delphi”. Historia, 6 (2): 160-175. 
La Anfictionía Pileo-Délfica y la solución judicial de controversias interestatales en el mundo griego clásico Emiliano J. Buis

FORREST, W. G. (1982). “Delphi 750-500 BCE”. Cambridge Ancient History, 3.3: 305-320.

FUNKE, Peter (2013). “Greek Amphiktyonies: An Experiment in Transregional Governance”. En Beck, Hans (ed.) A Companion to Ancient Greek Government. Chichester: John Wiley \& Sons: 451-465.

FUNKE, Peter (2016). "Was die Amphiktyonie im Innersten zusammenhält. Überlegungen zum Wechselspiel von Religion und Politik in zwischenstaatlichen Verfahren im frühen Griechenland", en Bonanno, Daniela, Peter Funke y Matthias Haake (eds). Rechtliche Verfabren und religiöse Sanktionierung in der griechisch-römischen Antike (Akten einer deutsch-italienischen Tagung, Palermo 11.-13. Dezember 2014). Stuttgart: Franz Steiner: 19-34.

GIOvanNINI, Adalberto (2007). Les relations entre États dans la Grèce antique du temps d'Homère à l'intervention romaine. Stuttgart: Franz Steiner.

GUILLERMAND, Jean (1994). "The Historical Foundations of Humanitarian Action". International Review of the Red Cross, 34: 194-216.

HALL, Jonathan M. (2002). Hellenicity: Between Ethnicity and Culture. Chicago: University of Chicago Press.

HALL, Jonathan M. (2007). “International Relations”, en Sabin, Philip, Hand van Wees y Michael Whitby (eds.). The Cambridge History of Greek and Roman W arfare, vol. 1. Cambridge: Cambridge University Press: 85-107.

HALL, Jonathan M. (2015). "Federalism and ethnicity", en Beck, Hans y Peter Funke (eds.). Federalism in Greek Antiquity. Cambridge: Cambridge University Press: 30-48.

HARTER-UibOPuU, Kaja (1998). Das zwischenstaatliche Schiedsverfahren im achä̈schen Koinon. Zur friedlichen Streitbeilegung nach den epigraphischen Quellen. Köln: Böhlau.

Hornblower, Simon (2007). "Did the Delphic Amphiktiony Play a Political Role in the Classical Period?”. Mediterranean Historical Review, 22 (1): 39-56.

ILARI, Virgilio (1980). Guerra e diritto nel mondo antico. Milano: Giuffrè.

KAHRSTEDT, Ulrich (1922). Griechisches Staatsrecht, vol. I. Göttingen: Vandenhoeck \& Ruprecht

KIECHLE, Franz (1958). “Zur Humanität in der Kriegführung der griechischen Staaten”. Historia, 7: 129156.

LARSEN, Jakob Aall Ottesen (1944). "Federation for Peace in Ancient Greece”. Classical Philology, 39: 145162.

LEFÈVRE, François (1995). "L’Amphictionie de Delphes : mythe et réalité”. Cahiers du Centre Gustave Glotz, 6: 19-31.

LEFÈVRE, François (1998). L'amphictionie pyléo-delphique: histoire et institutions. Paris: École Française d'Athènes. 
Revista Tribuna Internacional

Volumen $9 \cdot \mathrm{N}^{\mathrm{o}} 17 \cdot 2020$

ISSN 0719-482X (versión en línea)

LEFÈVRE, François (2005). "Les hiéromnémons de l'Amphictionie pyléo-delphique: l'apport de la prosopographie à l'histoire religieuse et politique de la Grèce ancienne". En Baslez, MarieFrançoise y Françoise Prévot (eds.). Prosopographie et histoire religieuse (Actes du colloque tenu en l'Université de Paris XII, Val de Marne, 27-28 octobre 2000). Paris: De Boccard: 9-34.

LOw, Polly (2007). Interstate Relations in Classical Greece. Morality and Power. Cambridge: Cambridge University Press.

LuRAGHI, Nino y Anna Magnetto (2012). “The Controversy between Megalopolis and Messene in a New Inscription from Messene”. Chiron, 42: 509-550.

MACKIL, Emily (2013a). Creating a Common Polity. Religion, Economy, and Politics in the Making of the Greek Koinon. Berkeley/Los Angeles/London: University of California Press.

MACKIL, Emily (2013b). “The Greek Koinon”. En Bang, Peter Fibiger y Walter Scheidel (eds.). The Oxford Handbook of the State in the Ancient Near East and Mediterranean. Oxford: Oxford University Press: 304-323.

MAgnetTo, Anna (2008). "Ricomporre il conflitto: la citta greca e l'arbitrato interstatale in eta classica ed ellenistica". En Lombardo, Mario (ed.). Forme sovrapoleiche e interpoleiche di organizzazione nel mondo Greco antico (Atti del convegno internazionale, Lecce, 17-20 settembre 2008). Galatina: Congedo: 175-184.

MAgnetTo, Anna (2016). "Interstate arbitration and foreign judges". En Harris, Edward M. \& Mirko Canevaro (eds.). The Oxford handbook of ancient Greek law. Oxford: Oxford University Press: 1-43.

MaLKIN, Irad (2011). A Small Greek World. Networks in the Ancient Mediterranean. Oxford: Oxford University Press.

Morgan, Catherine (1990). Athletes and Oracles. The Transformation of Olympia and Delphi in the Eighth Century $B C$. Cambridge/New York: Cambridge University Press.

NAKATEGAWA, Yoshio (1994). "Forms of Interstate Justice in the Late Fifth Century". Klio, 76: 135-154.

NIESE, Benedikt (1963). Geschichte der griechischen und makedonischen Staaten seit der Schlacht bei Chaeronea, vol. 2 "Vom Jahre 281 v. Chr. bis zur Begründung der römischen Hegemonie im griechischen Osten 188 v. Chr.". Gotha: Perthes.

PASCUAL, José (2007). "La sympoliteia griega en las épocas clásica y helenística”. Gerión, 25 (1): 167-186.

PÉREZ MARTIN, Elena (2001). Los extranjeros y el derecho en la antigua Grecia. Madrid: Dykinson.

PHILLIPSON, Coleman (1911). The International Law and Custom of Ancient Greece and Rome, vol. II. London: Macmillan \& Co. 
La Anfictionía Pileo-Délfica y la solución judicial de controversias interestatales en el mundo griego clásico Emiliano J. Buis

PICCIRILLI, Luigi (1972). "Aspetti storico-giuridici dell'anfizionia delfica e suoi rapporti con la colonizzazione greca”. Annali della Scuola Normale Superiore, 2: 35-61.

RAEDER, Anton (1912). L'arbitrage international chez les Hellènes, vol. I. Oslo: Christiania.

REINALDA, Bob (2009). Routledge History of International Organizations: From 1815 to the Present Day. London/New York: Routledge.

RitTBerger, Volker y Bernard Zangl (2006). International Organization: Polity, Policy and Politics. Basingstoke: Palgrave Macmillan.

RIZAKIS, Athanasios (2015). “The Achaian League”. En Beck, Hans y Peter Funke (eds.). Federalism in Greek Antiquity. Cambridge: Cambridge University Press: 118-131.

ROBERT, Louis (1973). "Les juges étrangers dans la cité grecque”. En von Caemmerer, Ernst, JosephHeinrich Kaiser y Gerhard Kegel (eds.) Xenion. Festschrift für Pan. J. Zepos. Athen/Freiburg/Köln: Katsikalis: 765-782.

RoEBUCK, Derek (2000). "Best to reconcile'. Mediation and arbitration in the ancient Greek world". Arbitration, 66: 275-287.

RoEBUCK, Derek (2001). Ancient Greek Arbitration. Oxford: Holo Books.

Roussel, Pierre (1940). “Athènes et l'amphictyonie delphique en 346”. Revue des Études Anciennes, 42 (14): $330-339$.

Roux, Georges (1979). L'Amphictionie, Delphes et le temple d'Apollon au IVe siècle. Lyon: Maison de l'Orient et de la Méditerranée Jean Pouilloux.

RZEPKA, Jacek (2002). “Ethnos, Koinon, Sympoliteia and Greek Federal States”. En Derda, Tomasz, Jakub

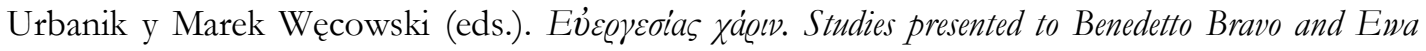
Wipsaycka by their Disciples (Journal of Juristic Papyrology, Suppl. 1). Warsaw: Fundacaja im. Rafała Taubenschlaga: 225-247.

SÁNCHEZ, P. (1997). "Le serment amphictionique [Aeschn., Legat. (2) 115]: un faux du IVe siècle?”, Historia 46; 158-71.

SÁNCHEZ, Pierre (2001). L'amphictionie des Pyles et de Delphes. Recherches sur son rôle historique des origines au IIe siècle de notre ère. Stuttgart: Franz Steiner.

SÁNCHEZ, Pierre (2013). “Amphictyony, Delphic”. En Bagnall, Roger S., Kai Brodersen, Craige B. Champion, Andrew Erskine y Sabine R. Huebner (eds.) The Encyclopedia of Ancient History. Malden/Oxford: Blackwell: 375-376.

SÉFÉRIADÈS, Stélio (1930). "Principes généraux du droit international de la paix". Recueil des Cours de l'Académie de La Haye, vol. 34. Leiden: Sijthoff: 177-492. 
Revista Tribuna Internacional

Volumen $9 \cdot \mathrm{N}^{\mathrm{o}} 17 \cdot 2020$

ISSN 0719-482X (versión en línea)

SINGOR, Henk (2009). "War and International Relations". En Raaflaub, Kurt A. y Hans van Wees (eds.). A Companion to Archaic Greece. Chichester: Wiley-Blackwell: 585-603.

TAUSEND, Klaus (1992). Amphiktyonie und Symmachie, Formen zwischenstaatlicher Beziehungen im archaischen Griechenland. Stuttgart: Franz Steiner.

TÉNÉKIDĖs, Georges (1931). "L'Amphictionie de Delphes et la ligue de Corinthe dans leurs affinités avec la Société des Nations". Revue générale de droit international public, 38: 5-20.

TÉNÉKIDÈS, Georges (1954). La notion juridique d'indépendance et la tradition bellénique. Autonomie et fédéralisme aux Ve et IVe siècles av. J.-C.. Athènes: Institut Français d'Athènes.

TÉNÉKIDĖS, Georges (1956). "Droit international et communautés fédérales dans la Grèce des cités (VeIIIe s. av. J.C.)". Recueil des cours de l'Académie de droit international de La Haye, 90 II. Leiden/Dordrecht: Martinus Nijhoff: 475-652.

TOD, Marcus Niebuhr (1913). International Arbitration among the Greeks. Oxford: Clarendon Press.

URUEÑA, René (2008). Derecho de las Organizaciones Internacionales. Bogotá: Universidad de Los Andes.

VINOGRADOFF, Paul (1922). Outlines of Historical Jurisprudence, vol. II. Oxford: Oxford University Press.

Vlassopoulos, Kostas (2007). Unthinking the Greek Polis. Ancient Greek History beyond Eurocentrism. Cambridge: Cambridge University Press.

WestermanN, William Linn (1907). "Interstate Arbitration in Antiquity”. The Classical Journal, 2 (5): 197 211. 